\title{
Cellular Fatty Acid Composition of Deleya halophila: Effect of Growth Temperature and Salt Concentration
}

\author{
By MERCEDES MONTEOLIVA-SANCHEZ ${ }^{1 *}$, M. RITA FERRER ${ }^{1}$, \\ ALBERTO RAMOS-CORMENZANA ${ }^{1}$, EMILIA QUESADA ${ }^{1}$ \\ AND MIGUEL MONTEOLIVA ${ }^{2}$ \\ ${ }^{1}$ Departamento de Microbiologia, Facultad de Farmacia, Universidad de Granada, \\ 18001 Granada, Spain \\ ${ }^{2}$ Unidad de Bioquimica, Instituto Lopez-Neyra de Parasitología, CSIC, 18001 Granada, Spain
}

(Received 27 April 1987; revised 12 August 1987)

The cellular fatty acid composition of Deleya halophila, a moderately halophilic bacterium, grown at different temperatures and $\mathrm{NaCl}$ concentrations is reported. When the temperature was lowered the amounts of monounsaturated $C_{16: 1}$ and $C_{18: 1}$ fatty acids increased with a corresponding decrease in the amounts of saturated $C_{16: 0}$ and $C_{18: 0}$ fatty acids. Increasing the salt concentration in the medium resulted in an increase of cyclopropane fatty acids, with a concomitant decrease in the monounsaturated fatty acids, suggesting that cyclopropane synthetase is activated or induced by high levels of salt.

\section{INTRODUCTION}

Deleya halophila is a moderately halophilic bacterium isolated from hypersaline soils (Quesada et al., 1984). This micro-organism is capable of growing over a wide range of salt concentrations $\left(2.5-25 \%, \mathrm{w} / \mathrm{v}\right.$, total salts) giving optimal growth at $7.5 \%$ when cultured at $32{ }^{\circ} \mathrm{C}$ (Ferrer et al., 1987).

The biochemistry of moderately halophilic bacteria has only recently been investigated in detail. However, little is known about the regulatory mechanisms of membrane structure and function in saline environments. It has been suggested that $\mathrm{NaCl}$-induced alterations of membrane lipid composition may be important in controlling the ionic permeability of halotolerant or halophilic bacteria (Hiramatsu et al., 1980; Komaratat \& Kates, 1975; Ohno et al., 1979), and it is of interest to determine how the physicochemical properties of the membranes are regulated to adapt to a range of salinities.

Alterations in fatty acid composition occur in some moderately halophilic bacteria with changes in salinity (Hanna et al., 1984; Monteoliva-Sanchez \& Ramos-Cormenzana, 1986, 1987 a; Ohno et al., 1979), and it has been suggested that perhaps the salt-dependent changes in fatty acid composition are mechanisms for regulating not lipid fluidity but lipid phase (Russell \& Kogut, 1985).

Here we report the results of a study undertaken to examine how temperature- and saltconcentration-dependent changes in the fatty acid composition of $D$. halophila could contribute to membrane integrity in this moderately halophilic bacterium.

\section{METHODS}

Organism and culture conditions. The bacterium used was D. halophila CCM 3662. Cells were grown in the moderately halophilic (MH) medium described by Quesada et al. (1983), supplemented with a balanced mixture of sea salt (Subov, 1931) to give a final concentration of $3,7.5$ or $20 \%(w / v$, total salts). The growth temperatures used were 20,32 and $40^{\circ} \mathrm{C}$. All cultures were incubated in an orbital shaker, harvested in the exponential or stationary phase by centrifugation at $10000 \mathrm{~g}$ for $15 \mathrm{~min}$ at $4{ }^{\circ} \mathrm{C}$, washed twice with cold saline containing $\mathrm{NaCl}$ at a concentration equal to that in the growth medium, and lyophilized. 


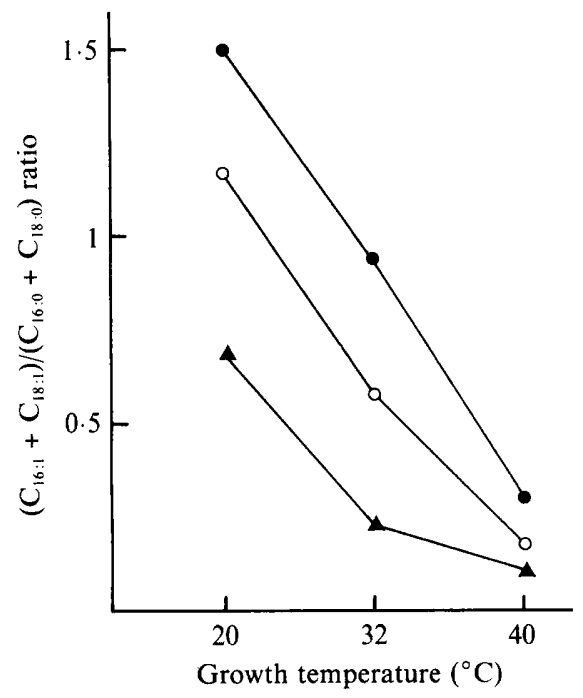

Fig. 1

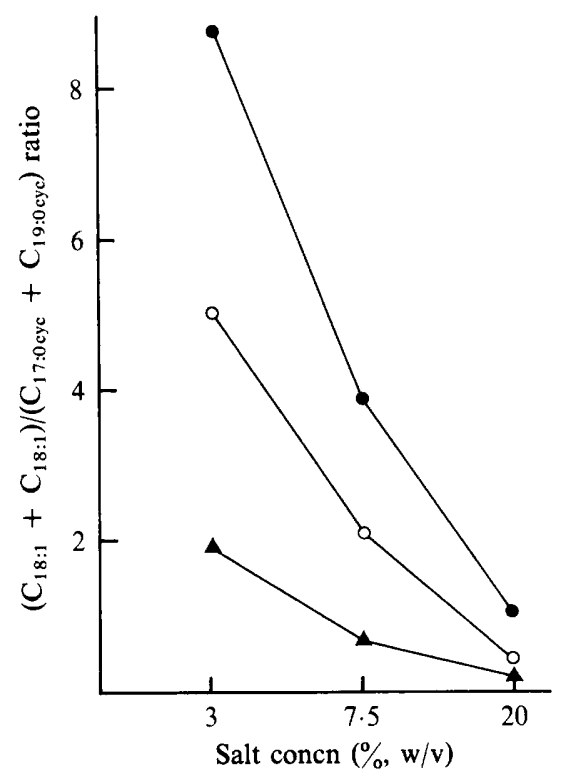

Fig. 2

Fig. 1. Effect of growth temperature on the ratio of monounsaturated fatty acids $\left(C_{16: 1}+C_{18: 1}, \% w / w\right)$ and saturated fatty acids $\left(C_{16: 0}+C_{18: 0}\right)$ of $D$. halophila grown to stationary phase at different salt concentrations: $3 \%(O), 7.5 \%(O)$ and $20 \%(\Delta)$.

Fig. 2. Effect of salt concentration on the ratio of monounsaturated fatty acids $\left(C_{16: 1}+C_{18: 1}, \% w / w\right)$ and cyclopropane fatty acids $\left(C_{17: 0 \mathrm{cyc}}+\mathrm{C}_{19: 0 \mathrm{cyc}}\right)$ of $D$. halophila grown to stationary phase at different temperatures: $20^{\circ} \mathrm{C}(\mathrm{O}), 32^{\circ} \mathrm{C}(\mathrm{O})$ and $40^{\circ} \mathrm{C}(\Delta)$.

Fatty acid analysis. Fatty acid methyl esters (FAMEs) were prepared from dried cells by saponification and heated with anhydrous methanol acidified with $\mathrm{H}_{2} \mathrm{SO}_{4}$ (Saito \& $\mathrm{McElhaney,} \mathrm{1977).} \mathrm{FAMEs} \mathrm{were} \mathrm{examined} \mathrm{by}$ GLC as previously described by Monteoliva-Sanchez \& Ramos-Cormenzana (1987b).

In addition a second $2 \mathrm{~m}$ non-polar column ( $3 \%$ methyl silicone, SE-30, on 80/100 mesh Gas-Chrom Q) was used to identify the FAMEs. To confirm the identity of unsaturated and cyclopropane fatty acids, hydrogenation and bromination were done as described by Brian \& Gardner (1968).

\section{RESULTS}

Under optimal culture conditions (a salt concentration of $7.5 \%$ at $32{ }^{\circ} \mathrm{C}$ ), the major fatty acid components were $C_{16: 0}$ and $C_{18: 1}$, together with significant proportions of $C_{16: 1}, C_{18: 0}$ and $\mathrm{C}_{17: 0 \mathrm{cyc} \text {. }}$

The effect of temperature on the fatty acid composition of $D$. halophila is shown in Table 1 and Fig. 1. When the temperature was lowered, the proportions of both $\mathrm{C}_{16: 1}$ and $\mathrm{C}_{18: 1}$ increased, with a corresponding decrease in the proportions of saturated $C_{16: 0}$ and $C_{18: 0}$ acids. However, the relative proportions of the cyclopropane fatty acid $C_{17: 0 c y c}$ appeared to be unaffected by temperature; these results were similar for all the salt concentrations investigated.

The fatty acid composition of $D$. halophila was altered when cells were grown in media containing different salt concentrations (Table 1, Fig. 2). For each growth temperature studied, the relative proportion of cyclopropane fatty acids, $\mathrm{C}_{17: 0 \mathrm{cyc}}$ and $\mathrm{C}_{19: 0 \mathrm{cyc}}$, increased as the salt concentration of the growth medium was raised, with a concomitant decrease of both monounsaturated $C_{16: 1}$ and $C_{18: 1}$ fatty acids. The relative proportion of saturated $C_{16: 0}$ acid was constant with variations in the salt concentration at the three temperatures studied.

To determine whether the phase of growth influenced the fatty acid composition, cells in the exponential and stationary phases grown with $3,7.5$ and $20 \%$ salt concentration were analysed (Table 2). No large changes in the total fatty acid composition as a function of growth phase 
Table 1. Fatty acid composition of D. halophila at the stationary phase of growth as a function of growth temperature and salt concentration

Values are expressed as $\%(w / w)$ and are means of three determinations, each using a different batch of cells. In each case, the SD values were not greater than $0.70 \%$ of the mean.

\begin{tabular}{|c|c|c|c|c|c|c|c|c|c|}
\hline \multirow[b]{3}{*}{ Fatty acid } & \multicolumn{9}{|c|}{ Salt concn $(\%, w / v)$ : } \\
\hline & \multirow[b]{2}{*}{$\begin{array}{l}\text { Temp. } \\
\left({ }^{\circ} \mathrm{C}\right) \ldots\end{array}$} & \multicolumn{2}{|l|}{$\underbrace{3}$} & \multicolumn{3}{|c|}{$\overbrace{}^{7.5}$} & \multicolumn{3}{|c|}{$\underbrace{20}$} \\
\hline & & 32 & 40 & 20 & 32 & 40 & 20 & 32 & 40 \\
\hline \multicolumn{10}{|l|}{ Saturated } \\
\hline$C_{10: 0}$ & $T$ & $0 \cdot 37$ & $0 \cdot 30$ & ND & ND & $\mathrm{T}$ & $0 \cdot 12$ & 1.89 & 0.90 \\
\hline $\mathrm{C}_{11: 0}$ & $0 \cdot 66$ & $0 \cdot 16$ & $0 \cdot 74$ & $\mathrm{~T}$ & $0 \cdot 31$ & 0.46 & 0.63 & $0 \cdot 37$ & 0.96 \\
\hline $\mathrm{C}_{12: 0}$ & 2.05 & 1.77 & $2 \cdot 29$ & $1 \cdot 20$ & 1.91 & $2 \cdot 59$ & $2 \cdot 83$ & $2 \cdot 42$ & $2 \cdot 86$ \\
\hline$C_{13: 0}$ & 1.06 & $2 \cdot 72$ & $2 \cdot 84$ & 1.95 & $2 \cdot 49$ & $2 \cdot 47$ & $1 \cdot 15$ & $2 \cdot 71$ & 2.09 \\
\hline $\mathrm{C}_{14: 0}$ & 2.05 & $2 \cdot 16$ & $2 \cdot 15$ & 1.53 & 3.86 & $3 \cdot 21$ & $3 \cdot 20$ & $4 \cdot 30$ & $3 \cdot 44$ \\
\hline$C_{15: 0}$ & 0.94 & 1.08 & $1 \cdot 04$ & $0 \cdot 24$ & $0 \cdot 12$ & $\mathrm{~T}$ & $\mathrm{~T}$ & $\mathrm{~T}$ & $\mathbf{T}$ \\
\hline$C_{16: 0}$ & 28.89 & 34.97 & 43.68 & $29 \cdot 02$ & $35 \cdot 33$ & $41 \cdot 67$ & $28 \cdot 86$ & 33.82 & $40 \cdot 43$ \\
\hline $\mathrm{C}_{17: 0}$ & $\mathrm{~T}$ & ND & ND & ND & $\mathrm{T}$ & ND & ND & ND & ND \\
\hline $\mathrm{C}_{18: 0}$ & $3 \cdot 01$ & $4 \cdot 30$ & $9 \cdot 88$ & $6 \cdot 13$ & $8 \cdot 32$ & $11 \cdot 81$ & $7 \cdot 56$ & $10 \cdot 30$ & $11 \cdot 41$ \\
\hline $\mathrm{C}_{19: 0}$ & $1 \cdot 36$ & $\mathrm{~T}$ & ND & $T$ & ND & ND & $\mathrm{T}$ & $1 \cdot 20$ & 0.75 \\
\hline $\mathrm{C}_{20: 0}$ & 1.56 & $1 \cdot 70$ & 1.91 & 0.94 & $1 \cdot 37$ & $1 \cdot 50$ & 0.83 & 0.93 & 1.05 \\
\hline \multicolumn{10}{|l|}{ Branched } \\
\hline br- $C_{14: 0}$ & 0.31 & 0.96 & 0.69 & $1 \cdot 71$ & $2 \cdot 52$ & $1 \cdot 51$ & 1.92 & $1 \cdot 28$ & $1 \cdot 75$ \\
\hline $\mathrm{br}-\mathrm{C}_{15: 0}$ & $4 \cdot 65$ & 4.41 & $6 \cdot 75$ & $5 \cdot 65$ & $5 \cdot 34$ & $8 \cdot 70$ & $4 \cdot 78$ & $5 \cdot 58$ & 5.79 \\
\hline br- $C_{16: 0}$ & ND & ND & ND & ND & ND & ND & ND & ND & ND \\
\hline br $-C_{17: 0}$ & $0 \cdot 35$ & $1 \cdot 13$ & $2 \cdot 06$ & $0 \cdot 12$ & 0.54 & 1.08 & $\mathbf{T}$ & $0 \cdot 12$ & 0.53 \\
\hline \multicolumn{10}{|l|}{ Unsaturated } \\
\hline $\mathrm{C}_{16: 1}$ & $13 \cdot 10$ & $9 \cdot 53$ & $7 \cdot 75$ & $10 \cdot 80$ & $8 \cdot 82$ & $4 \cdot 20$ & 6.59 & 3.99 & $2 \cdot 23$ \\
\hline $\mathrm{C}_{18: 1}$ & $35 \cdot 54$ & $27 \cdot 35$ & $8 \cdot 38$ & $30 \cdot 04$ & $16 \cdot 88$ & 5.95 & 18.75 & $6 \cdot 22$ & $2 \cdot 82$ \\
\hline \multicolumn{10}{|l|}{ Cyclopropane } \\
\hline $\mathrm{C}_{17: 0 \mathrm{cyc}}$ & 4.43 & $4 \cdot 88$ & $6 \cdot 31$ & 8.52 & $9 \cdot 01$ & 9.78 & 11.93 & $12 \cdot 52$ & $12 \cdot 68$ \\
\hline $\mathrm{C}_{19: 0 \mathrm{cyc}}$ & $1 \cdot 01$ & $2 \cdot 48$ & $2 \cdot 17$ & 2.09 & $3 \cdot 12$ & $3 \cdot 08$ & $10 \cdot 75$ & $12 \cdot 27$ & $10 \cdot 19$ \\
\hline
\end{tabular}

were observed, although cultures in the exponential phase contained more monounsaturated fatty acids and less saturated fatty acids than cultures in the stationary phase. There was a small increase in the proportion of cyclopropane fatty acids in the stationary phase cultures compared with the exponential phase cultures at the three salt concentrations investigated.

\section{DISCUSSION}

Investigation of the changes in fatty acid composition of cells grown under extreme conditions of temperature and salt concentration should be useful for studying the relationship between the fatty acid composition of lipids and their physical properties relevant to growth in halophilic environments. This study is the first report on the fatty acid composition of $D$. halophila CCM 3662, and has shown that it was significantly affected by the incubation temperature and salt content of the growth medium.

The predominant alteration in fatty acid composition detected in response to a decrease in growth temperature was an increase in unsaturation (Fig. 1). These results are in accord with earlier findings for other bacteria (Melchior, 1982; Russell, 1984). The increase in unsaturation may be due to an increase in the amount of the dehydrase/desaturase enzyme (Cronan, 1975) or the altered activity of enzymes at lower temperatures (Sinensky, 1971). The exact influence of temperature on physical properties of the membrane of $D$. halophila cannot be deduced from the present results since compositional effects may partly counteract one another (Barran \& Miller, 
Table 2. Effect of phase of growth on the fatty acid composition of $D$. halophila grown at $32{ }^{\circ} \mathrm{C}$ and at different salt concentrations

Values are expressed as $\%(w / w)$ and are means of three determinations, each using a different batch of cells. In each case, the SD values were not greater than $0.70 \%$ of the mean.

\begin{tabular}{|c|c|c|c|c|c|c|}
\hline \multirow[b]{3}{*}{ Fatty acid } & \multicolumn{6}{|c|}{ Salt concn $(\%, w / v)$} \\
\hline & \multicolumn{2}{|c|}{3} & \multicolumn{2}{|c|}{$7 \cdot 5$} & \multicolumn{2}{|c|}{20} \\
\hline & Exp. & Stat. & Exp. & Stat. & Exp. & Stat. \\
\hline \multicolumn{7}{|l|}{ Saturated } \\
\hline $\mathrm{C}_{10: 0}$ & $0 \cdot 28$ & $0 \cdot 37$ & $0 \cdot 12$ & ND & 0.84 & 1.89 \\
\hline $\mathrm{C}_{11: 0}$ & $T$ & $0 \cdot 16$ & $0 \cdot 20$ & $0 \cdot 31$ & $0 \cdot 26$ & 0.37 \\
\hline$C_{12: 0}^{11: 0}$ & 0.40 & 1.77 & 0.46 & 1.91 & $2 \cdot 61$ & $2 \cdot 42$ \\
\hline$C_{13: 0}$ & $2 \cdot 45$ & $2 \cdot 72$ & 2.98 & 2.49 & $2 \cdot 87$ & $2 \cdot 71$ \\
\hline $\mathrm{C}_{14: 0}$ & $1 \cdot 80$ & $2 \cdot 16$ & $2 \cdot 64$ & $3 \cdot 86$ & $4 \cdot 83$ & $4 \cdot 30$ \\
\hline $\mathrm{C}_{15: 0}$ & $1 \cdot 12$ & $1 \cdot 08$ & $0 \cdot 15$ & $0 \cdot 12$ & $0 \cdot 21$ & $\mathbf{T}$ \\
\hline $\mathrm{C}_{16: 0}$ & $32 \cdot 64$ & 34.97 & 33.84 & $35 \cdot 33$ & $32 \cdot 62$ & $33 \cdot 82$ \\
\hline $\mathrm{C}_{17: 0}$ & ND & ND & ND & $\mathrm{T}$ & $\mathrm{T}$ & ND \\
\hline $\mathrm{C}_{18: 0}$ & $3 \cdot 86$ & $4 \cdot 30$ & $7 \cdot 37$ & $8 \cdot 32$ & $8 \cdot 86$ & $10 \cdot 30$ \\
\hline $\mathrm{C}_{19: 0}$ & ND & $T$ & ND & ND & $\mathrm{T}$ & $1 \cdot 20$ \\
\hline $\mathrm{C}_{20: 0}$ & $0 \cdot 38$ & $1 \cdot 70$ & $T$ & $1 \cdot 37$ & $T$ & 0.93 \\
\hline \multicolumn{7}{|l|}{ Branched } \\
\hline $\mathrm{br}-\mathrm{C}_{14: 0}$ & 0.84 & 0.96 & $2 \cdot 13$ & $2 \cdot 52$ & 1.93 & $1 \cdot 28$ \\
\hline br- $C_{15: 0}$ & $4 \cdot 66$ & $4 \cdot 41$ & $4 \cdot 42$ & $5 \cdot 34$ & $4 \cdot 02$ & $5 \cdot 58$ \\
\hline br- $C_{16: 0}$ & ND & ND & ND & ND & ND & ND \\
\hline br $-C_{17: 0}$ & $1 \cdot 40$ & $1 \cdot 13$ & 0.94 & 0.54 & $\mathbf{T}$ & $0 \cdot 12$ \\
\hline \multicolumn{7}{|l|}{ Unsaturated } \\
\hline $\mathrm{C}_{16: 1}$ & 12.95 & $9 \cdot 53$ & $11 \cdot 46$ & $8 \cdot 82$ & $7 \cdot 19$ & 3.99 \\
\hline $\mathrm{C}_{18: 1}$ & $31 \cdot 08$ & $27 \cdot 35$ & $21 \cdot 69$ & $16 \cdot 88$ & $11 \cdot 10$ & $6 \cdot 22$ \\
\hline \multicolumn{7}{|l|}{ Cyclopropane } \\
\hline $\mathrm{C}_{17: 0 \mathrm{cyc}}$ & 3.95 & $4 \cdot 88$ & $8 \cdot 47$ & 9.01 & $11 \cdot 19$ & $12 \cdot 52$ \\
\hline $\mathrm{C}_{19: 0 \mathrm{cyc}}$ & $2 \cdot 06$ & $2 \cdot 48$ & 3.09 & $3 \cdot 12$ & $11 \cdot 38$ & $12 \cdot 27$ \\
\hline \multicolumn{7}{|l|}{ Growth rate } \\
\hline Generation time (h) & $1 \cdot 38$ & $9 \cdot 62$ & $1 \cdot 18$ & $6 \cdot 30$ & 1.95 & $10 \cdot 66$ \\
\hline Incubation time (h) & $12 \cdot 00$ & $26 \cdot 00$ & $12 \cdot 00$ & $26 \cdot 00$ & $16 \cdot 00$ & $30 \cdot 00$ \\
\hline
\end{tabular}

Exp, exponential cultures. Stat, stationary cultures. T, Trace content of less than $0.1 \%$. ND, Not detected.

1976), and also the change in growth rate with change in temperature may contribute to changes in lipid composition (Brown \& Rose, 1969). The compositional adaptation may serve to maintain a constant membrane fluidity in response to temperature changes (McElhaney, 1976).

Increasing the salt concentration resulted in a decrease in the proportion of monounsaturated fatty acids with a concomitant increase in cyclopropane fatty acids (Fig. 2). In the non-halophile Escherichia coli growth in the presence of 0.3 and $0.6 \mathrm{M}-\mathrm{NaCl}$ resulted in an increase of cyclopropane fatty acids, detected only at the stationary growth phase (McGarrity \& Armstrong, 1975, 1981). However, for the moderately halophilic bacterium Pseudomonas halosaccharolytica, cyclopropane fatty acid content is apparently increased by added $\mathrm{NaCl}$ at all growth stages (Ohno et al., 1979). The compositional alterations of the cyclopropane fatty acids in $D$. halophila, detected at both the exponentiai and the stationary phase of growth (Table 2) more closely resemble the alteration observed for the moderate halophile $P$. halosaccharolytica than that for the non-halophile $E$. coli.

Ohno et al. (1979) reported that in $P$. halosaccharolytica an increase in either growth temperature or $\mathrm{NaCl}$ concentration promoted the formation of cyclopropane fatty acids from the corresponding monounsaturated fatty acids. In the moderate halophile Flavobacterium halmephilum (Monteoliva-Sanchez \& Ramos-Cormenzana, 1986) only an increase in the salt concentration caused the formation of cyclopropane fatty acids. 
The moderate halophile $D$. halophila exhibited phenotypic adaptation to changes in salt concentration. This adaptation process involved changes in the fatty acid composition, especially in the relative amounts of cyclopropane fatty acids. The fact that increased salt concentration led to an increase in cyclopropane fatty acids and a concomitant decrease in the corresponding monounsaturated fatty acids in $D$. halophila suggests that cyclopropane synthetase is activated or induced by high salt concentrations, and could indicate that the intracellular cyclopropane fatty acids are indispensable for $\mathrm{Na}^{+}$permeability in some moderately-halophilic bacteria.

\section{REFERENCES}

BARRAN, L. J. \& MILLER, R. W. (1976). Temperatureinduced alterations in phospholipids in Fusarium oxysporum f.sp. lycopersici. Canadian Journal of Microbiology 22, 557-562.

Brian, B. L. \& Gardner, E. W. (1968). A simple procedure for detecting the presence of cyclopropane fatty acids in bacterial lipids. Applied Microbiology 16, 549-552.

Brown, C. M. \& Rose, A. H. (1969). Fatty acid composition of Candida utilis as affected by growth temperature and dissolved-oxygen tension. Journal of Bacteriology 99, 371-378.

Cronan, J. E., JR (1975). Thermal regulation of the membrane lipid composition of Escherichia coli. Journal of Biological Chemistry 250, 7074-7077.

Ferrer, M. R., Del Moral, A., Quesada, E. \& Ramos-CoRmenzana, A. (1987). Growth rate and some physiological features of Deleya halophila CCM 3662 at different salt concentrations. Annales de l'Institut Pasteur/Microbiologie 138, 49-57.

HaNNA, K., Bengis-Garber, C., Kushner, D. J., Kogut, M. \& Kates, M. (1984). The effect of salt concentration on the phospholipid and fatty acid composition of the moderate halophile Vibrio costicola. Canadian Journal of Microbiology 30, 669-675.

Hiramatsu, T., Ohno, Y., Hara, H., Yano, I. \& MASUI, M. (1980). Effects of $\mathrm{NaCl}$ concentration on the envelope components in a moderately halophilic bacterium, Pseudomonas halosaccharolytica. In $\mathrm{Sa}$ line Environments. Proceedings of the Japanese Conference on Halophilic Microbiology, pp. 189-199. Edited by $\mathbf{M}$. Morishita \& M. Masui. Kyoto, Japan: Nakanishi Printing Co.

Komaratat, P. \& Kates, M. (1975). The lipid composition of a halotolerant species of Staphylococcus epidermis. Biochimica et biophysica acta 398 464-484.

MCElHaney, R. N. (1976). The biological significance of alterations in the fatty acid composition of microbial membrane lipids in response to changes in environmental temperature. In Extreme Environments : Mechanisms of Microbial Adaptation, pp. 255281. Edited by H. R. Heinrich. New York: Academic Press.

MCGarrity, J. T. \& ARMSTrong, J. B. (1975). The effect of salt on phospholipid fatty acid composition in Escherichia coli K-12. Biochimica et biophysica acta 398, 258-264.

MCGarrity, J. T. \& ARMSTRONG, J. B. (1981). The effect of temperature and other growth conditions on the fatty acid composition of Escherichia coli. Canadian Journal of Microbiology 27, 835-840.
MELCHIOR, D. L. (1982). Lipid phase transitions and regulation of membrane fluidity in prokaryotes. Current Topics in Membranes and Transport 17, 263316.

Monteoliva-Sanchez, M. \& Ramos-CoRmenzana, A. (1986). Effect of growth temperature and salt concentration on the fatty acid composition of Flavobacterium halmephilum CCM 2831. FEMS Microbiology Letters 33, 51-54.

Monteoliva-Sanchez, M. \& Ramos-CoRmenzana, A. $(1987 a)$. Cellular fatty acid composition of Planococcus halophilus NRCC 14033 as affected by growth temperature and salt concentration. Current Microbiology 15, 133-136.

MontEoliva-SancheZ, M. \& Ramos-CoRmenzana, A. (1987b). Cellular fatty acid composition in moderately halophilic Gram-negative rods. Journal of Applied Bacteriology 62, 361-366.

OHNo, Y., Yano, I. \& Masui, M. (1979). Effect of $\mathrm{NaCl}$ concentration and temperature on the phospholipid and fatty acid composition of a moderately halophilic bacterium, Pseudomonas halosaccharolytica. Journal of Biochemistry 85, 413-421.

Quesada, E., Ventosa, A., Rodriquez-Valera, F., MEgias, L. \& Ramos-Cormenzana, A. (1983). Numerical taxonomy of moderately halophilic Gram-negative bacteria from hypersaline soils. Journal of General Microbiology 129, 2649-2657.

Quesada, E., Ventosa, A., Ruiz-Berraquero, F. \& Ramos-Cormenzana, A. (1984). Deleya halophila, a new species of moderately halophilic bacteria. International Journal of Systematic Bacteriology 34, 287292.

RUSSELL, N. J. (1984). Mechanisms of thermal adaptation in bacteria: blueprints for survival. Trends in Biochemical Sciences 9, 108-112.

RusSELl, N. J. \& KogUT, M. (1985). Haloadaptation: salt sensing and cell-envelope changes. Microbiological Sciences 2, 345-350.

SaITo, Y. \& McElhaney, R. N. (1977). Membrane lipid biosynthesis in Acholeplasma laidlawii B: incorporation of exogenous fatty acids into membrane glyco- and phospholipids by growing cells. Journal of Bacteriology 132, 485-496.

SINENSKY, M. (1971). Temperature control of phospholipid biosynthesis in Escherichia coli. Journal of Bacteriology 106, 449-455.

Subov, N. N. (1931). Oceanographical Tables. Moscow, USSR: USSR Oceanographical Institute. 